\title{
'The Emperor is Naked!': Exposing (In) efficiency of Self- Assessment and Group - Assessment in Higher Education
}

\author{
Inga Minelgaite ${ }^{1}$, Rasa Nedzinskaitè-Mačiūniené ${ }^{2}$ Kari Kristinsson ${ }^{3}$, Sigurdur Gudjonsson ${ }^{4}$ \\ University of Iceland, School of Business, Gimli v. Saemundargata, 101 Reykjavik, Iceland, inm@hi.is \\ Vytautas Magnus University, K. Donelaičio g. 58, LT-44248, Kaunas, Lithuania, rasa.nedzinskaite-maciuniene@vdu.lt \\ University of Iceland, School of Business, Gimli v. Saemundargata, 101 Reykjavik, Iceland, karik@hi.is \\ University of Iceland, School of Business, Gimli v. Saemundargata, 101 Reykjavik, Iceland, siggig@hi.is
}

Abstract. In this study, we examine how students grade themselves in comparison with their peers and teachers. Results were formed from a sample of 169 first-year students signed up to the course "Introduction to Management", run by the School of Business at the University of Iceland and based on a cooperative learning strategy. Irrespective of whether students were evaluating their individual or group work, the mean outcomes suggest that their own grading is much higher than that of their peers, and higher again than their teachers. These results suggest that the self-interest of the Homo economicus was clouding objectivity, and it is also likely that the inexperience of the new undergraduates in such grading approaches played a role. Future research should not abandon the idea of self-assessment as a means of developing critical capacities among students, but rather seek to explore whether these results are replicated in other educational settings, such as different disciplines and sub-disciplines, and whether more experienced students, such as third-year undergraduates, demonstrate similar behavioral responses.

Keywords: higher education, students, self-assessment, group self-assessment, homo economicus.

\section{Introduction}

In a rapid change of society, where technology is influencing all spheres of life, and the emergence of automation via robotization, competencies required from people are changing. Correspondingly, the education field may need to adapt to provide the skills 
of the future. Then the question arises - what kind of person does modern society need? What competencies should they have? For example, industry 4.0 is suggesting a totally different set of competencies than before. In this vein, greater priority needs to be afforded to competencies that are difficult to define or measure, such as complex problem solving, critical thinking, creativity, people management, emotional intelligence, leadership, decision-making, negotiation, cognitive flexibility, etc. (World Economic Forum, 2016). The majority of the above-mentioned competencies relate to the ability to critically evaluate oneself and an ability to foresee a further plan of action, which overall can be termed self-assessment.

Since the middle of the 20th century, researchers have focused on students' selfassessment or self-evaluation in higher education settings. Student's self-assessment has been widely studied in comparison with teacher assessment (Boud, Falchikov, 1989a; Falchikov, Boud, 1989b), peer-, and group-assessment (Roberts, 2006), and self-, peer-, and teacher assessment (Lindblom-Ylänne, Pihlajamäki, Kotkas, 2006). Self-assessment is aninseparable part of lifelong learning, and is inherent in self-regulated learning (Kosnin, 2007), and self-efficacy (Panadero, Jonsson, Botella, 2017). The proper application of self-assessment in the educational process is linked to better learning outcomes (Roberts, 2006; Schunk, 2012), transparency of assessment (Ross, Starling, 2008), active involvement in studies (Buchanan, 2004), and enables teachers to track and record students' individual progress and efforts in the learning process.

Recent focus has expanded the view on self-assessment, including also peer-assessment (Roberts, 2006). A variety of factors have been indicated in the literature that effect self-assessment, for example, the learning environment, such as e-learning (Roberts, 2006), as well as theexperiencesstudents have with self-assessment (Amo and Jareno, 2011). Furthermore, different learning environments or contexts, such as study disciplines, suggest differences in the self-assessment of students in different disciplines e.g. medical students have been reported as possessing atendency to underrate themselves (Falchikov and Boud, 1989b, Cassidy, 2007). Even though trends in self-assessment with medical (healthcare) students is well recorded in the literature, empirical evidence regarding students in business administration is rare. This article addresses the gap by investigatingtheindividual and group self-assessment of business administration students, as a way of gaining a better understanding of the effectiveness and coherenceof self-assessment with intended outcomes (Cassidy, 2007).

The research question is: Do self-and group-assessment work with business students in higher education? The question emerges from existing contradictions. On the one hand, today's electronic and informational reality suggests the need for new competenciesinthe job market, including reflective qualities such asflexibility, critical thinking, leadership, and people orientation. On the other hand, there remains evidencethat the neoliberal (Anglo-Saxon) education model is dominant, which is oriented to more short term goals, and where education is understood through a pragmatic-technological lens. Besides 
that,business studies are closely correlated with markets and their changes. Therefore, in this article, the focus is on self- and group- assessment in higher education. Importantly, we reflect on "homus economicus" as human behavior in the light of business studies, and students' ability for self- and group-assessment. The article provides relevant ideas and results for both theory and practice.

\section{Literature review}

\section{Homo economicus in business education}

Although the social sciences have relied on very different behavioral assumptions, economics - and by extension, business studies - has historically been unique to its reliance on Homo economicus as the model of human behavior (Blaug, 1997). The term is a word play on homo sapiens and is used for teaching purposes as well as mathematical modeling. In short, the Homo economicus model of human behavior assumes that individuals are entirely self-interested, consistently rational and instantly maximizing agents that pursue their goals optimally without care for others. This is a view that Veblen criticized for describing individuals as a "lightning calculator of pleasures and pains" (Veblen, 1919, 73-74). It is therefore no wonder that economists have never enjoyed an especially good reputation among their peers. The historian Thomas Carlyle famously described economics as the "dismal science" (Marglin, 2008) and later the psychoanalyst Donald Winnicott described economics as the science of greed (Winnicott, 1990). Giving credence to its critics are the results of experiments that show links between learning economics and behaving more selfishly. Economic students have been found to be more selfish than other students across various situations (Carter and Irons, 1991; Frank, Gilovich and Regan, 1996; Childs, 2012).

Different values of students in different disciplines have been researched. For example, Sjöberg and Engelberg (2009) found that the students of finance had a positive attitude to economic risk taking and gambling behavior, together with a high level of sensation seeking, a low level of money concernand they gave low priority to altruistic values regarding topeace and the environment. Meanwhile, business students do not have less knowledge about the environment, but they demonstrate less concern for it (Alan, $\mathrm{Au}$, 1997). Klein, Levenburg, McKendall, and Mothersell (2007) argue that compared to their counterparts in other academic fields, students in business and economics have a greater tendency to act in self-interested ways. This research suggests that business students have an attitude that can be considered more 'here and now', which underlies attempts to get instant results. Some of these studies suggest that business students are frequently described as having personality characteristics such as spontaneity, narcissism, and orientation towards results, and relatively less emphasis on care for the environment compared to their counterparts in other disciplines. 
Although business students learn more than economics during their degree, other subjects also teachrational and/or self-interested models of human behavior, with the theory of planned behavior being one of the most relevant ones taught in management and marketing (Ajzen, 1991). On the other hand, the students receive considerable lessons in ethical and socially responsible education. Despite that, there remainsevidence ofbusiness students' inabilityto see a broader context and display orientation to social responsibility. In other words, business students are challenged when moving beyond asingle-minded pursuit of profit and to think critically about the impact of business decisions upon external stakeholders (Seider, Gillmor, Rabinowicz, 2011). This paradox might be encoded in the profession itself, since during studies the focus is on developing competencies such as orientation towards a goal, effectiveness and efficiency, fast-paced results, low cost, high self-confidence and directiveness (Spencer, Spencer, 1993, Mintzberg, 2004). And all of this in essence is the value frame of Homo economicus. Therefore, the recently evolving idea of social responsibility in business is still too young and emergent to diminish or replacethe well-established economic-capitalistic approach.

\section{Self-, peer-, group-assessment in higher education}

Assessment is a crucial part of all learning processes. Self-assessment is defined as'the process of having the learners critically reflect upon, record the progress of, and perhaps suggest grades for, their own learning' (Roberts, 2006, 3). The ability to assess the work of one's group, as well as the ability of self-assessment is a 'vital skill in the real world' (Roberts, 2006, 3). Roberts (2006) suggests that the notion of group-assessment can mean different things - "from the assessment of group as a whole to the assessment of individuals within a group, to the group members assessing other group members' contributions to the group"' (p. 9). Meanwhile, peer assessment refers to the consideration of "the amount, level, value, worth, quality, or success of the products or outcomes of learning of peers of similar status" (Topping, 1998) and can includesuggesting the grades for the learning process of one's peers (Roberts, 2006).

All these assessment types refer to assessment $\underline{\text { as }}$ and for learning. The learner in this process must be able to reflect on the learning process of his or her group members or of the whole group, determine how much learning matches with the outlined criteria (criteria for assessment), and foresee further learning steps in order to achieve defined learning goals. Peer- and group-assessment requires learners to have critical thinking and an ability to provide constructive feedback to another learner or group of learners. Applying individual or group self-assessment strategies in the educational process, as indicated by the literature, should reduce the gap between current and desired outcomes. Thus, the self-assessment process requires learners to have metacognitive learning skills. The literature suggests (Weeden, Winter, Broadfoot, 2002; Cassidy, 2007) that every learner's metacognitive skills are not the same, therefore the ability to self-assess oneselfvaries. Boud and Falchikov (1989a), in their review,concluded that student skills 
inself-assessment are related with "learning strength", i.e. those students who are not acute learners, have a tendency to overrate their own work, and those who are acuteoften underrate their work, when compared with a teacher's assessment.

Cassidy (2007) conducted an analysis on co-study of first-year undergraduate (inexperienced) research, which revealed that there is a link between self-assessment and the learning style of individual students. Furthermore, the research concluded that there are significant correlations between students' self-assessment skills and a deep approach to learning. The findings of this study reaffirmed that adequate self-assessment relates to the 'experience' of students. In the same vein, Falchikov and Boud (1989b) suggest thatthe more experienced students are, the more they tend to underrate their own work. The above-mentioned findings are supported by Amo and Jareno (2011) in their research comparing first and third year students' self- and peer-assessment results. They concluded that in $70 \%$ of cases the first-year students overrated their performance compared to teacher scores. Meanwhile, in assessments of the third-year students, there were no cases of overrating. Similarresults were identifiedin the peer-assessment, where $64 \%$ of the first year students overrated their peers.

The ability to self-assess is related not only to experience and skills, but also to the discipline of study.Falchikov and Boud (1989b), and a later study by Cassidy (2007) revealed that students in healthcare science tended to underrate their performance. Similar conclusions were reached from the study of Minter et al. (2005) focused onresidents, where the results indicated an underestimation in self-assessments bythe students, when compared to faculty assessments. Minter et al. (2005) found significant statistical differences among all the residents, surgery residents, who were particularly inclined to underrate their own performance in self-assessment. Therefore, a conclusion can be drawn that there are differences in self-assessment among students in different disciplines, students of healthcare sciencesare too critical for self-assessment and evaluatingtheir results of learning processes in a more pessimistic light.

Although studies have shown that students lack the ability to self-assess themselves, it is much more difficult to assess the work done by others, e.g. other groups of students. The lack of these abilities is more evident, as students have even less experience of evaluating other people's work (Gibbs, 2009). In this vein, the research ofLindblom-Ylänne, Pihlajamäki and Kotkas (2006) concluded that students faced various difficulties when engaging in assessment, especially challenges such as being objective towards oneself or too critical towards a peer.

Overall, self-, peer- or group assessment is not an innate ability, irrespective of whether we associate it with deep-learning, meta-learning, or other levels of learning. It is important to recognize that self-assessment or assessing oneself as a member of the group, demands from students' particular skills and experience. Despite the findings of the above-mentioned studies, there is still a need for different forms of self-assessment in higher education. For example, Topping (1998) suggests that the use of peer-assessment 
in higher education develops cognitive, social, and transferable skills. This is due to the opportunities provided by peer-assessment to "gets into others shoes", i.e. becomes an assessor, but unlike the lecturer, understanding the situation, status and feelings differently.The importance of this necessity is also evident inanabundance of research (Dochy, Segers, Sluijsmans, 1999; Buchanan, 2004; Roberts, 2006; Schunk, 2012), which reveals that adequate self- and group-assessment:

- means better engagement with the course;

- helps to gain control of your own learning;

- facilitates reflection on your own learning;

- promotes student responsibility for their own learning;

- encourages abetter learning strategy;

- increases student satisfaction.

Another important conclusion that can be drawn from the literature is that adopting different assessment strategies (self-, peer-, or group-assessment) at the same time could encourage students to become more responsible and reflective on their own learning processes (Dochy, Segers, Sluijsmans, 1999). Thus, in order to attain academic achievements, it is necessary to apply both individual and group self-assessment in higher education, while cultivating students'metacognitive skills.

\section{Self-, peer-, group-assessment as a tools for self-regulated learning}

In the individual or group self-assessment processes students are active players. Already in 1975, Knowles noted that self-assessment is associated with propelling towards development of greater student autonomy in learning (Knowles, 1975). Therefore, students have to gain skills on regulating, controlling, and managing their own learning, in other words - they must take part in self-regulated learning (SRL).

Zimmerman (1994; 2002), in his ground-breaking work on the development of SRL theory, states that self-reflection and self-assessment are two key elements of SRL. However, in order to develop SLR, external feedback is vital, which in this case is provided by peers through peer-assessment. This feedback is crucial for bringing for enabling the internal and external mechanisms of control and management that would lead towards the development of SRL.Furthermore, in collaborative groups, SRL is strengthened through accountability towards group members. A meta-analytic review by Panadero, Jonsson and Botella (2017) concluded that self-assessment has a positive effect on students' SRL. In the same vein, Magno (2010), after once again testing the SRL measurement scale, concluded that self-assessment is a factor of SRL which is positively intercorrelated with other factors of SRL, such as memory strategy, goal-setting, seeking assistance, environmental structuring, learning responsibility, and organizing. In that sense, all (individual and group) self-assessment strategies are positively contributing towards students' SRL. SRL has a positive effect on students' overall academic success (Zimmerman, 2002). For example,a study by Kosnin (2007) of Malaysian engineering undergraduates revealed 
that SRL has a significant effect on students' academic achievement. However, an even more important conclusion drawn from this research is that those students with higher academic achievements have higher SRL.

As discussed above, adequate self-assessment, as well as SRL, is associated with learning achievements (high and low achievers). Therefore, the findings of various studies confirm that there isa close interrelation between SRL and self-assessment. As a result of self-assessment, both self-regulation and academic achievement can increase (Schunk, 2000). The aforementioned suggests that the ability of students to self-assess themselves relates to theirskills and experience. Therefore, it is not surprising that research with first-year students reveals a lack of self-regulation skills due to their lack of experience (Lumpijeva, Volkov, 2013). Lumpijeva and Volkov (2013) concluded that "new generation" students are unable to verbalize the text, find it difficult to understand complex material, can process information only in small parts, are unable to independently organize their time, and find it challenging tocontrol their learning. Therefore, in order to achieve students' SRL, it is necessary to divide the material into smaller parts and provide the optimal conditions for self-assessment after each part. Furthermore, it is crucial to organize student group work appropriately so that they can learn to provide feedback as one of the peer-assessment elements.

\section{Methodology}

The main research focus of this study was to investigate how students carry out selfassessment and self-evaluation for assignments. The course "Introduction to Management" was based on acooperative learning strategy. This strategy has 5 elements, but in our article we concentrate one just one of these - processing. It relates tothe process when group members assess their collaborative efforts and target improvements (Bennet, et al, 1991). The element of processing concerns self-assessment and self-evaluation processes at individual and group (and between groups) levels in our case. The students were divided into groups of 7 students and their task was to make an educational video on the course subject. After the video was presented in front of the whole class, each student was asked to evaluate his or her contribution to the project and send it to the teachers.

\section{Procedure and participants}

First year undergraduate students at the University of Iceland studying management were asked to evaluate by themselves the own work they carried out in the video assignment. The students who participated in our survey are on their first year of their studies and during their course in "Introduction to Management", they learned about ethics in relation to stakeholder theory, where others stakeholders, such as employees, suppliers, the surrounding community and many others, are to be taken into consideration. Thus 
the course emphasizes that pure self-interest is not the sole purpose of an organization, nor should it be the only goal of an individual. Furthermore, the students learn about corporate social responsibility in the course "Strategy", where they study about laissez-faire, enlightened self-interest and stakeholder interaction, enabling them to become a shaper of the wider society. The study was carried out over one semester and students were tasked to produce agroup assignment and thengive their peers a grade, as well as to evaluate themselves. The students were informed that they would receive agrade partly dependent on their self-assessment grade. Out of the 169 students, $50 \%$ were female and $50 \%$ were male.

\section{Measurements}

We used grades from first year BS students in Management course at the University of Iceland. Students were asked to evaluate themselves, evaluate each other and evaluate the group as a whole. In the following section the result from the individual self-assessment will be presented as well as the result from the group assessment will be briefly discussed.

\section{Results}

The main result is that there is limited use of self-assessment, since the vast majority of the students gave themselves the highest possible grade or 10. In fact, the average grade students gave themselves was 9.79. Furthermore, only 13 percent of all students evaluated their contribution as lessthan 10 .

As can be seen in figure 1, out of 165 students only $13 \%$ thought their contribution was worth less than a perfect grade.

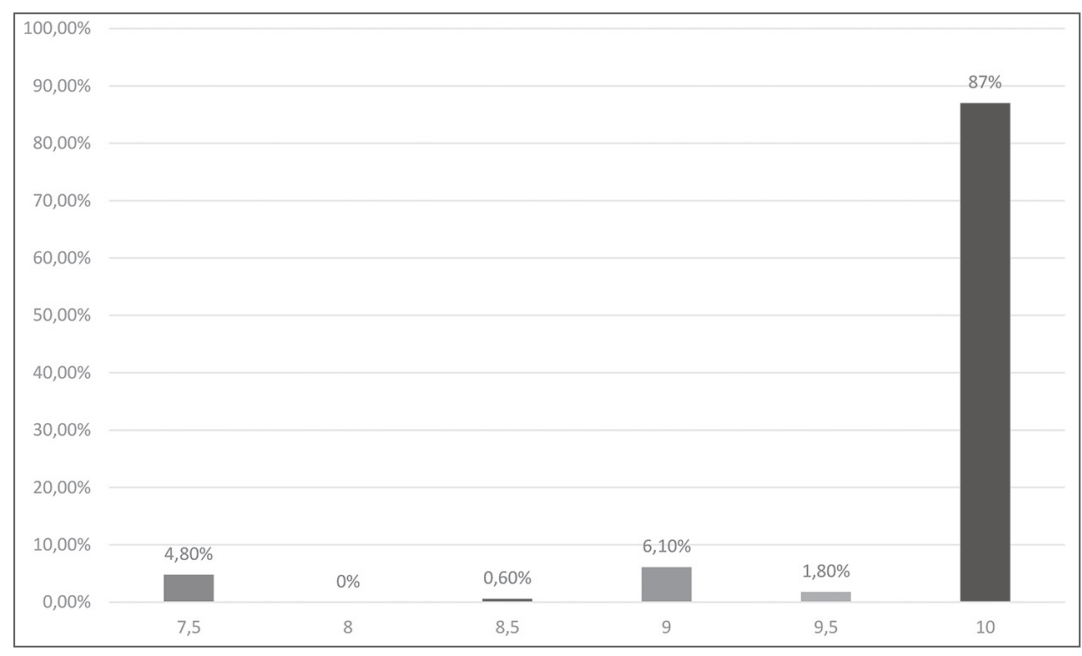

Figure 1. Student individual self-assessmentgrades 
From figure 1 we can see that the students gavethemselves very high grades in their self-assessment process. Almost all of them gave themselves 9 orabove. Only 8 students rated themselves modestly with agrade of 7.5 and no studentgraded themselveslower than that. Almost $87 \%$ of the students evaluated their work as outstanding and believed they deserved the highest grade possible of 10 .

It is noteworthy to see that the average grade students received from their assignment valued by their teachers is 8.51 which is much lower than their meanself-assessment grade of 9.14. The student peer assessment was also lower than the student's self-assessment of 8.80 but higher than provided bythe teacher.

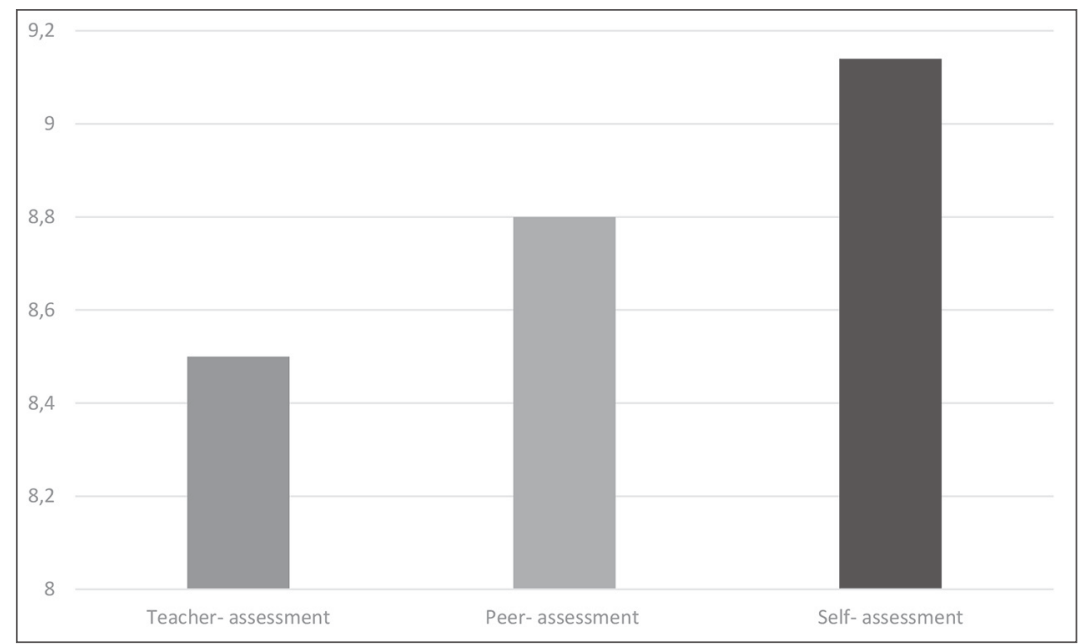

Figure 2. Individual self-assessment, teacher-assessment and peer-assessment

As we can see in figure 2 above, students rate themselves much higher than the teachers and peers. The use of self-assessment is therefore misleading at best.

As for the student's group involvingself-assessment, the average grade the groups gave themselves was 9.78. Out of 34 groups, 30 of them gave themselves 10, the highest grade possible, equating to more than $88 \%$ of the groups. One group stated they deserved 9.5 which is less than $3 \%$ of the groups, two groups rated themselves at 8.5 (less than $6 \%$ of the total), and finally one group gave themselves a 6.5 . Only $3 \%$ of the groups stated that they deserve a grade of lower than 8.5. See figure 3.

From figure 3 we can see that most of the groups evaluated themselves with the highest possible grade of 10 or $88 \%$ of the total. Only four groups did not give themselves the highest possible grade, one of whichstated the next best grade of 9.5, two graded themselves at 8.5 , and one modest group claimed that they deserved 6.5. 


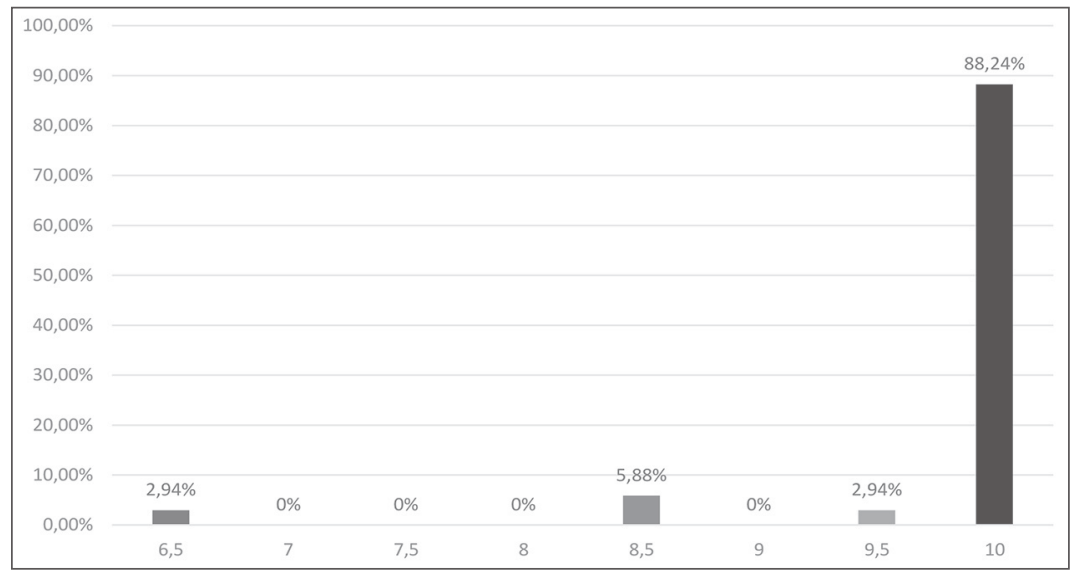

Figure 3. Percentage of grades given by group self-assessment

If we compare individual self-assessment and group-assessment, we see a very similar trend. The students gave themselves the highest possible grade, both as individuals and in groups. See figure 4 below.

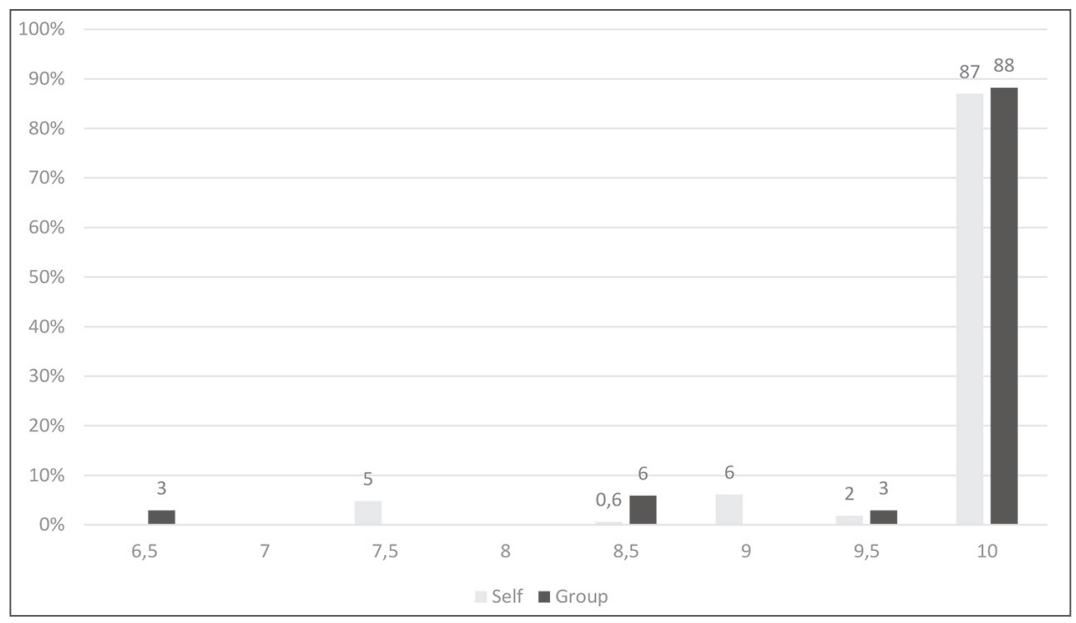

Figure 4. Individual self-assessment and group self-assessment

From figure 4 we can see that the students give themselves the highest possible grade of 10 in most cases. This is the case both when they are performing as individuals and members of a group.

We also examined if there is a gender difference inself-assessment. The results do not imply any gender differences in self-assessment. About $88 \%$ of males gave themselves full grades whereas $89 \%$ of women did. As can be seen in figure 5 , the average grade males gave themselves was 9.79 while the average forfemales gave was marginally higherat 9.81 . The grade for the groupas a whole was 9.79 . 


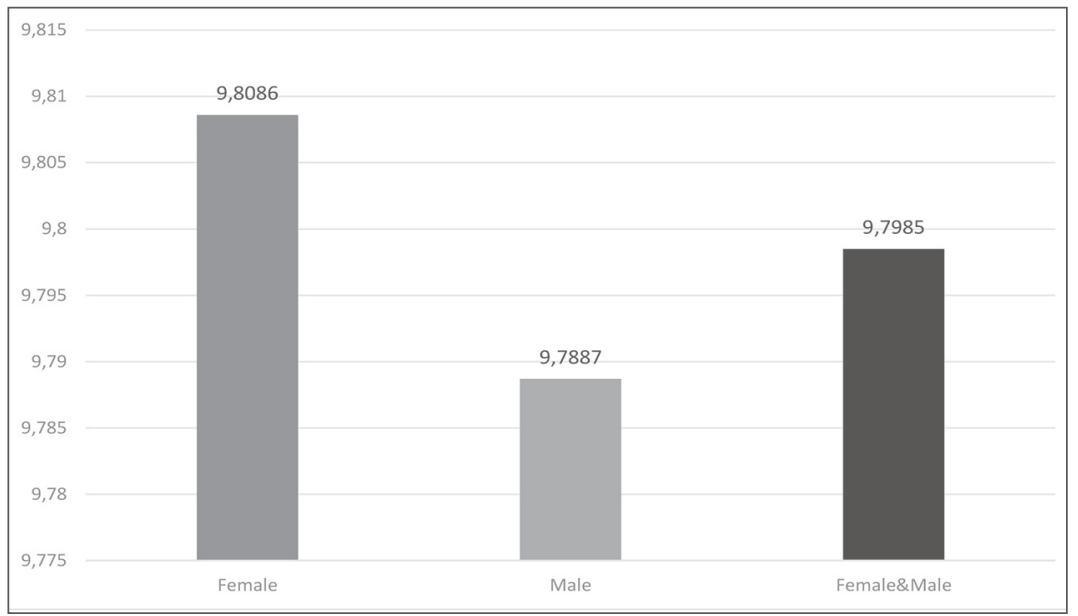

Figure 5. Average individual self-assessment grades by Gender

In figure 5 we can clearly see that the grades males and females graded themselves for the self-assessment process are almost the same. There is a marginal difference that does not support the idea that there are gender differences in self-assessment.

As can be seen in figure 6, even those that did not evaluate their contribution as outstanding (10) did not give themselves low grades. If we examine only those who did not grade themselves with the highest possible grade, we can see that the average grade of women was 8.5 , while the average grade was 8.4 .

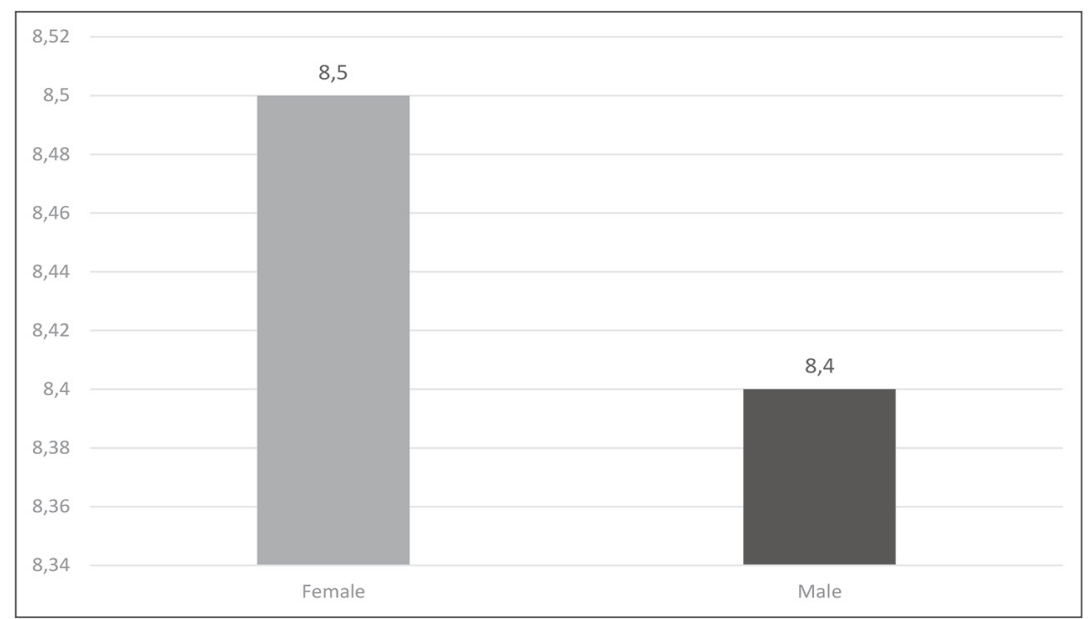

Figure 6. Average self-assessment grades of those who did not give themselvesthe grade 10 by gender

In figure 6 we can see that those who did not give themselves the highest possible grade or 10 for self-assessment, there is no difference between the genders. As for the group 
self-assessmentwe find no noticeable gender difference. Therefore, there is no gender difference for individual self-assessment or group self-assessment between males or females.

\section{Conclusion and implications for future research}

The present study has gone some way towards providing answers to our questions regarding how self- and group- assessment work with business students. The results of the research raise certain questions for discussion. Herewe elaborate on a few of them.

First, our research indicated that more than $87 \%$ of students evaluated their own work, individual and in groups, with the highest possible grade. The first glance at these results might give an impression that these are students who cannot adequately and critically evaluate themselves. Indeed, the object of the research were first- year bachelor students. It is in line with the literature that there are differences in abilities to self-assess between new and more experienced students. For example, Amo and Jareno (2011) research with the first and third -year students in Spain revealed that the first-year students aremore inclined to overrate themselves than third year students, when compared with a teacher's evaluation. Boud and Falchikiv (1989a), in their review, concluded that student skills in self-assessment are related to "learning strength", and that those students who are not acute learners have a tendency to overrate their own work, and those who are acute often underrate their work, when compared with teacher's assessment. Such outcomes are explained by aperson's level of metacognitive learning ability and SRL. Therefore, in the case of our research results, they lead to a logical conclusion, because, as indicated in the literature, a person needs to have experience and abilities in order to self-assess. These results bring us to the conclusion that in order to self-assessadequately for students, individually and in group-assessment, they need to cultivate these skills. That means that in the process of studying, self-, peer-, and group- assessment needs to form an integral component of the evaluation.

Secondly, this research confirms that a gender aspect in the context of self-evaluation is not a relevantfactor. A body of literature has also addressed gender differences in the self-assessment of students. For example, Mattheos, et al. (2004), in their study with medical students, concluded that even though all the students overestimated their competence in relation to the judgment of their instructors, with females performing better than males, no statistically significant difference was found among genders in selfassessment. In the same vein, the study of Andrade and $\mathrm{Du}$ (2007) found no statistically significant difference in self-assessment between male and female students. However, the study conducted by Minter et al. (2005) found that no that female students in medical science demonstrated a greater degree of underestimation than did their male counterparts. Therefore, we suggest, in the same vein as Boud and Falchikov concluded in1989, that the gender question in self-evaluation research has not yet reached a conclusive stage and should be researching more in the future. 
A body of literature on self-assessment in different disciplines of study, together with our research with business students, presents yet another direction for future research. In our study we investigated self-assessment in business students. Analysis of scientific studies (Falchikov, Boud,1989b; Cassidy, 2007, Minter et al., 2005) showed a general tendency for medical students to underrate themselves in self-evaluation. This tendency is well-recorded in scientific literature and calls for more research with students from other disciplines. Furthermore, the variations in thedegreeof underestimation in self-assessment among different sub-disciplines of medical students, suggests possible differences in the fields (or sub-fields) of study, and hence should be researched.

Our results are in line with studies that indicate that economics and business students are more self-interested than students in other disciplines (Klein, Levenburg, McKendall, and Mothersell, 2007). Although the literature seems to be in agreement on this result (Childs, 2012), it has also indicated that self-interested behavior is highly context dependent (Kangas, 1997). This has been found to be especially true as individuals gain more experience in their environment, as getting feedback regarding what behavior is incentivized and legitimized tends to influence future behavior (Heilman and Martell, 1986; Ezell, Odewahn and Sherman, 1981; Marlowe, Schneider and Nelson, 1996). These scholars point out that individuals learn from their experience and therefore behavior that is socially frowned upon should disappear as people have a chance to change their behavior to better suit the incentives present in the environment. Our results should therefore not be viewed in a negative light. It is quite possible that as students gain more experience their behavior will become less self-interested, a result that is in line with the findings of some scholars (Falchikov and Boud, 1989b; Amo and Jareno, 2011). Thus, by changing the incentives presented to students, as well as allowing them to gain more experience in self-assessment, this might prove sufficient for students to change their behavior to a more objective self-assessment concerning their grading.

\section{References}

Ajzen, I. (1991). The Theory of Planned Behavior. Organizational Behavior and Human Decision Processes, 50(2), 179-211.

Are New Zealand Business Students More Unethical than Non-Business Students? Journal of Business Ethics, 16(4), 445-450.

Amo, E., Jareno, F. (2011). Self, Peer and Teacher Assessment as Active Learning. Research Journal of Internatıonal Studies, 18, 41-47.

Andrade, H., \& Du, Y. (2007). Student Responses to Criteria-Referenced Self-Assessment. Assessment \& evaluation in higher education, 32(2), 159-181.

Bennet, B., Rolheiser, C., Stevahn, L. (1991). Cooperative Learning: Where Heart Meets Mind.

Ontario: Professional Development Associates 
Blaug, M. (1997). Economic Theory in Retrospect. Cambridge university press.

Boud, D., Falchikov, N. (1989a). Quantitative Studies of Student Self-Assessment in Higher Education: A Critical Analysisof Findings. Higher Education, 18(5), 529-549.

Buchanan, E. A. (2004). Online Assessment in Higher Education: Strategies to Systematically Evaluate Student Learning. In C. Howard, K. Schenk \& R. Discenza (EDS.). Distance Learning and University Effectiveness: Changing Educational Paradigms for Online Learning. Herskey, PA: Information Science Publishing.

Carter, J. R., \& Irons, M. D. (1991). Are Economists Different, and if so, why?. Journal of Economic Perspectives, 5(2), 171-177.

Cassidy, S. (2007). Assessing 'Inexperienced' Students' Ability to Self-Assess: Exploring Links with Learning Style and Academic Personal Control. Assessment \& Evaluation in Higher Education, 32(3), 313-330.

Childs, J. (2012). Demonstrating the Need for Effective Business Ethics: an Alternative Approach. Business and Society Review, 117(2), 221-232.

Dochy, F., Segers, M., Sluijsmans, D. (1999). The Use of Self-, Peer and Co-assessment in Higher Education: A Review. Studies in Higher Education, 24(3), 331-350

Falchikov, N., Boud, D. (1989b). Student Self-Assessment in Higher Education: A Meta-Analysis. Review of Educational Research, 59 (4), 395-430.

Frank, R. H., Gilovich, T. D., \& Regan, D. T. (1996). Do Economists Make Bad Citizens?. Journal of Economic Perspectives, 10(1), 187-192.

Gibbs, G. (2009). The Assessment of Group Work: Lessons from the Literature. Assessment Standards Knowledge Exchange. UK: Brooks University.

Kangas, O. E. (1997). Self-Interest and the Common Good: the Impact of Norms, Selfishness and Context in Social Policy Opinions. The Journal of Socio-Economics, 26(5), 475-494.

Klein, H. A., Levenburg, N. M., McKendall, M., \& Mothersell, W. (2007). Cheating During the College Years: How Do Business School Students Compare? Journal of Business Ethics, 72(2), 197-206.

Knowles, M. S. (1975). Self-Directed Learning: A Guide for Learners and Teachers. New York: Association Press

Kosnin, A. M. (2007). Self-Regulated Learning and Academic Achievement in Malaysian Undergraduates. International Education Journal, 8(1), 221-228.

Lindblom-Ylänne, S., Pihlajamäki, H., Kotkas, T. (2006).Self-, Peer- and Teacher-Assessment of Student Essays. Active Learning in Higher Education, 7(1), 51-62.

Lumpijeva, T. P., Volkov, A. F. (2013). Generation Z: The Psychological Characteristics of Modern Students. In Problems and Ways of Improvement of Scientific-Methodical and Educational Work in DonNTU. Donetsk: DonNTU. [Lumpieva, T. P., Volkov, A. F. (2013). Pokolenie Z: psihologičeskie osobennosti sovremennyh studentov.Problemy i shlyakhy vdoskonalennya naukovo-metodychnoyi ta navchal'no-vykhovnoyi roboty $v$ DonNTU. Donets'k: DonNTU] Retrieved from: http://ea.donntu.edu.ua:8080/jspui/handle/123456789/21748

Magno, C. (2010). Assessing Academic Self-Regulated Learning among Filipino College Students: The Factor Structure and Item Fit. The International Journal of Educational and Psychological Assessment, 5, 61-76. 
Marglin, S. A. (2008). The Dismal Science: How Thinking Like an Economist Undermines Community. Harvard University Press.

Gender and Attractiveness Biases in Hiring Decisions: Are More Experienced Managers Less Biased?. Journal of applied psychology, 81(1), 11.

Mattheos, N., Nattestad, A., Falk-Nilsson, E., \& Attström, R. (2004). The Interactive Examination: Assessing Students' Self-Assessment Ability. Medical education, 38(4), 378-389.

Mintzberg, H. (2004). Managers Not MBA's. Prentice Hall, Financial Times, Pearson Education.

Panadero, E., Jonsson, A., Botella, J. (2017). Effects of Self-Assessment on Self-Regulated Learning and Self-Efficacy: Four Meta-Analyses. Educational Research Review, 22, 74-98

Roberts, T. S. (2006). Self, Per, and Group Assessment in E-Learning: An Introduction. In: Self, Peer and Group Assessment in E-Learning. Edit: Roberts, T. S. Hershey, London, Melbourne, Singapore: Information Science Publishing, 1-16

Ross, J. A., Starling, M. (2008). Self-Assessment in a Technology Supported Environment: The Case of Grade 9 Geography. Assessment in Education: Principles, Policy \& Practice, 15 (2), 183-199.

Schunk, D. (2012). Learning Theories: an Educational Perspective. 6th Edition. Boston, New York et al.: Pearson.

Seider, S. C., Gillmor, S. C., \& Rabinowicz, S. A. (2011). The Impact of Community Service Learning upon the Worldviews of Business Majors Versus Non-Business Majors at an American University. Journal of Business Ethics, 98(3), 485-503.

Sjöberg, L., \& Engelberg, E. (2009). Attitudes to Economic Risk Taking, Sensation Seeking and Values of Business Students Specializing in Finance. The Journal of Behavioral Finance, 10(1), 33-43.

Spencer, L. M., Spencer, S. M. (1993) Competence at Work. Hoboken, NJ: John Wiley\&Sons, Inc The Future of Jobs: Employment, Skills and Workforce Strategy for the Fourth Industrial Revoliution. (2016). World Economic Forum.

Topping, K. (1998). Peer Assessment between Students in Colleges and Universities. Review of Educational Research, 68(3), 249-276.

Veblen, T. (1919). The Place of Science in Modern Civilization. New York: B. W. Huebsch

Weeden, P., Winter, J., Broadfoot, P. (2002). Assessment: What's in It for Schools? London and New York: Routledge / Falmer (Taylor \& Francis Group).

Winnicott, D. W. (1990). Home Is Where We Start From: Essays by a Psychoanalyst. WW norton \& Company.

Zimmerman, B. J. (1994). Dimensions of Academic Self-Regulation: A Conceptual Frame- Work for Education. In D. H. Schunk \& B. J. Zimmerman (Eds.), Self-Regulation of Learning and Performance: Issues and educational applications (pp. 3-21). Hillsdale, NJ: Erlb

Zimmerman, B. J. (2002). Becoming a Self-Regulated Learner: An Overview. Theory into Practice, 41(2), 64-70. 


\title{
„Karalius nuogas!“便dividualaus ir grupinio ịsivertinimo (ne)efektyvumas aukštajame moksle
}

\author{
Inga Minelgaitè ${ }^{1}$, Rasa Nedzinskaitè-Mačiūnienè2, Kari Kristinsson ${ }^{3}$, Sigurdur Gudjonsson ${ }^{4}$ \\ Islandijos universitetas, Vadybos fakultetas, Gimli v. Saemundargata, 101 Reikjavikas, Islandija, inm@hi.is \\ Vytauto Didžiojo universitetas, K. Donelaičio g. 58, 44248, Kaunas, rasa.nedzinskaite-maciuniene@vdu.lt \\ Islandijos universitetas, Vadybos fakultetas, Gimli v. Saemundargata, 101 Reikjavikas, Islandija, karik@hi.is \\ Islandijos universitetas, Vadybos fakultetas, Gimli v. Saemundargata, 101 Reikjavikas, Islandija, siggig@hi.is
}

\section{Santrauka}

Straipsnyje siekiama atskleisti, ar individualus ir grupinis savęs vertinimas yra efektyvus dirbant su verslo studentais. Tokią mokslinę problemą ėmėmès tyrinèti dèl esamų tam tikrų prieštarų. Kaip žinia, verslo studijos yra glaudžiai susijusios su verslo rinka ir jos kaita. Viena vertus, kalbama apie pasikeitusius reikalavimus asmens gebejimams darbo rinkoje, t. y. lankstumas, kritinis mąstymas, lyderystè, orientacija įžmones ir t. t. Tačiau verslo rinkos pasaulyje vis dar akcentuotini į tikslą orientuoti asmens gebejjimai, tokie kaip greito rezultato pasiekimas mažomis sąnaudomis, nepaslankumas. Tad vertybiškai verslo studijų studentų ir rengimas, ir veikimas rinkoje pagrịstas homo economicus principu. Ir apskirai žvelgdami ị švietimo sferą matome vis dar gajų neoliberalų švietimo modelị, kuris yra orientuotas ị trumpalaikius tikslus, o švietimas suprantamas per pragmatinę-technologinę prizmę. Todèl šiame tyrime buvo ịdomu, ar individualus ir grupinis ịsivertinimas yra efektyvus dirbant su verslo studentais, kadangi isivertinimas (bet kuria forma) reikalauja iš asmens kritinio mąstymo, reflektavimo, ilgalaikių tikslų numatymo ir pan.

Tyrimas atliktas Islandijos universiteto Verslo fakultete su pirmojo kurso studentais ( $\mathrm{N}=169)$. Tiriamieji klausė kursą Itvadas ị vadybą, kuris buvo paremtas mokymosi bendradarbiaujant strategija. Šiame straipsnyje atskleidžiama, kaip taikytant šią strategiją studentai individualiai ir grupeje įsivertino savo ir grupès darbą. Duomenys atskleidè, kad studentai tiek individualiai, tiek grupès lygmeniu yra linkę savo darbą pervertinti ir skiria sau aukščiausius įvertinimus. Be to, studentai yra linkę save vertinti geriau nei dėstytojas. Tiriamuoju atveju nenustatyta savęs vertinimo skirtumų lyties atžvilgiu.

Taigi straipsnyje ne tik aktualizuojami individualus ir grupinis įsivertinimas aukštajame moksle, ị verslo studentų ịsivertinimą žvelgiama per homus economicus prizmę, bet ir teikiamos ¡žvalgos, kurios yra aktualios ir teorijai, ir praktikai.

Esminiai žodžiai: aukštasis mokslas, studentai, i̊sivertinimas, grupès įsivertinimas, 'homo economicus’. 